\title{
THE OMBUDSMAN COMES TO ALBERTA
}

\section{GEOFFREY SAWER*}

\begin{abstract}
Once a state accepts the concept of an ombudsman the question arises: What are the appropriate statutory provisions for empowering and regulating such an office? Professor Sawer answers this question by comparing the Alberta and New Zealand statutes. He also suggests that Alberta Lawyers rearrange the Ombudsman's case reports under legal headings and then use them as precedents in future complaints to the Ombudsman.
\end{abstract}

\section{(i) Ombudsmen in General and in Alberta}

Alberta was the fourth Commonwealth country, after New Zealand, Guyana and the United Kingdom, and the first in North America, to establish an Ombudsman.' The governing Ombudsman Act assented to on 30 March, 1967, like the Guyana Act of 1965, and unlike the U.K. Parliamentary Commissioner Act 1967, is closely modelled on the pioneer New Zealand Parliamentary Commissioner (Ombudsman) Act 1962. The office originated in Sweden, from whence it spread to Finland, Denmark and Norway. In its modern form, it is an informal method of enabling citizens to make complaints about the operations of government to an administrative officer having a high degree of independence from the general executive government, and from the party politics of legislatures; if the Ombudsman thinks the governmental activity in question seems prima facie open to objection, he investigates it by direct approach to the relevant officials and scrutiny of relevant government files, and if he then thinks that the governmental action has been in a fairly broad sense unfair to the complaining citizen, he may (if the administrator has not meanwhile taken appropriate action) suggest some way of putting the matter right and/or of avoiding similar situations in the future. But he has no power of coercion, nor of substituting a different decision on his own authority, and if he cannot persuade the relevant administrators to change or modify the activity which caused the complaint, his only sanction is to report the matter to a relevant legislature. (In Scandinavia, some Ombudsmen have power to initiate or direct legal action against erring officials, if the act complained of is specifically illegal.) The Ombudsman has therefore to rely in the main on the persuasive power which he can develop through his personality, his reputation for objectivity and wisdom and the prestige of his office, with an assist from the possibilities of publicity available through reports to Parliament and to the Press. ${ }^{2}$

- Professor of Law, The Research School of Social Sciences, The Australlan National University.

1 Mauritius and New Brunswick had also at writing enacted necessary legislation, but not made an appointment. In 1966, the Legislative Council of the Australian Northern Territory passed an Ordinance to establish an Ombudsman. but the Governor-General on advice from the Commonwealth (federal) Government disallowed the Ordinance.

* For the origins and present operation of the office, see particularly D. C. Rowat (ed.). The Ombudsman (1965). W. Gellhorn, Ombudsmen and Others (1966), and G. Sawer. Ombudsmen (2nd ed. 1967). A forthcoming number of the Annals of the American Academy of Political and Social Science, and a symposium entitled Ombudsmen for American Government shortly to be published under the auspices of the American Assembly should also be consulted. The periodical literature is now large. and in general reference may be made to the many papers by the Scandinavian ambudsmen. Alfred Bexclius (Sweden) and Stephan furwitz (Denmark), and by Sir Guy Powles, Ombudsman in New Zealand. 
In the span of remedies-administrative, political and judicial-available to the citizen against the government, the Ombudsman procedure occupies a position between the administrative-political ones, on the one hand, and the judicial on the other. The citizen may be able to get some distance by direct representations to a relevant department or authority, but even the highest officers in a particular hierarchy, including the political Minister, may be loth to disturb an initial decision by a more junior officer and still more loth to depart from a decision of their own. If the citizen turns to political representations, through his local Assembly member or an appropriate legislative Committee, he may obtain satisfaction, but the forces of politics may defeat him, and indeed a distrust of or distaste for politicians in general or for the particular Member or party majority involved may deter him from attempting such a recourse. Generally speaking, the administrative-political recourse is apt to lack the qualities of objective, dispassionate reconsideration, directed solely to the purpose of attending to the individual grievance. Those qualities are amply present if the question can be and is brought before a Court. But in the Anglo-Canadian-Australian legal systems, there is no specialized jurisdiction to deal with the special problem of remedies against governments, such as the French Conseil d'Etat, and the remedies supplied by the ordinary legal system have many defects, in particular expense, rigidity and incompleteness. Some of the defects in the administrative-political remedies and in the judicial ones are capable of amendment, and a good many reformers have urged the amendment of those remedies rather than the introduction of an additional recourse. However, my own view is that there is probably an irreducible minimum of subjective bias and political distortion in the administrative-political recourse, and of cost and rigidity in the judicial. In the relatively unreformed situation-which is that of all the Commonwealth and United States governmental and legal systems today-the room for a third type of recourse is evident, and I think it is likely to remain a most useful recourse even after extensive amendments to the rest of the system. This third recourse, the Ombudsman, has the cheapness and flexibility in operation of administrative and political action, and the objectivity and reliability of judicial decision. The characteristic vices of the Ombudsman recourse derive from its reliance on the personal characteristics of the officer and on persuasion. It would not be practicable to have an infinite regression of Ombudsmen to keep an eye on the primary Ombudsman, so that he himself must be outstanding. Lacking coercive power, the Ombudsman is sometimes defeated because his ultimate masters, the legislators, will not back him up; in practice, he is more likely to develop a strong sense of the possible, and to avoid getting into a position where an administrator can successfully call his bluff.

Ombudsmen can perform several auxiliary purposes, in addition to the investigation of specific individual grievances, and the extent to which they do this depends to some extent on their formal powers and even more on the characteristic style of operation of a particular man or the traditional style of a particular country's office. Free or cheap legal advice is almost inevitably supplied to complaining citizens, even where (as often happens) the complainant is told to pursue an available legal remedy. Suggestions for law reform usually result from the 
case experience of Ombudsmen, and the Alberta-New Zealand Acts in terms encourage such suggestions. The mere existence of the Ombudsman is likely to produce greater care among administrators, and after a time the cumulative effect of Ombudsman suggestions is certain to produce improvements in the form and substance of administration, and in its tone and style. By relieving legislators of part of their constituency 'case work', the Ombudsman enables them to concentrate more on their proper business of general legislative and administrative policy. In view of the Swedish history of the institution, it may seem odd not to mention that an Ombudsman may be the eyes and ears of the legislature in relation to the misdeeds of the administration, but this is less likely to be important under our system of responsible government, and would become important only if a legislative Standing Committee maintained continuous contact with the Ombudsman's work.

The Alberta Ombudsman is appointed by the Lieutenant Governor in Council for a five-year term, and is removable only on Assembly recommendation for cause:" $\mathrm{He}$ is an officer of the Assembly, and his salary is charged on consolidated revenue, but he is dependent for staff on appointments under the Public Service Act. ${ }^{+}$His function is to investigate decisions, acts, and omissions to act 'relating to a matter of administration' which affect some person, natural or legal, either on complaint or of his own motion; certain administrative activities are excluded, and the Ombudsman has discretion to decline investigation in some cases." The main mandatory exclusions are: where an appeal on the merits is available, has not been exhausted and is not time-barred; matter concerning the legal service of the Crown. The main discretionary exclusions are: existence of adequate remedy, legal or administrative (other than petition to the Legislature); matter more than 12 months old; complaint trivial or vexatious; lack of personal interest. The Ombudsman is required to inform the permanent head of the department or agency before starting an enquiry and a Minister may require consultation; subject to this, the Ombudsman is given extensive powers of requiring disclosure and production of documents, including power to examine on oath, and only information and documents concerning Executive Council proceedings may (on certificate of the Attorney General) be withdrawn from disclosure." The Ombudsman is required to find whether the act in question is illegal, unreasonable, founded on mistake of fact or law, or 'wrong', or in the case of a discretionary decision whether it was exercised for improper purpose, or on irrelevant grounds or considerations, or without the giving of adequate reasons; he may suggest appropriate steps to deal with the situation, in the light of his findings. ${ }^{i}$ If he considers that a decision was properly taken under a law or practice which itself is unreasonable, oppressive or discriminatory, he may recommend a change in the law or practice." The Ombudsman reports the result of his enquiry to the complainant; if his views are not complied with in a reasonable time, he reports the matter to the Lieutenant

3 The Ombudsman Act, S.A. 1967, c. 59. ss. 3. 6.

1 Id. ss. 3. 10.

i Id. ss. 11, 12, 14.

i: Id. ss. 15, 16, 17, 18.

7 Id. s. 20.

i Id. s. $20(1)(b), 20(3)$ (d). 
Governor and to the Assembly, and he makes an annual report to the Assembly. ${ }^{9}$

\section{(ii) The Alberta and New Zealand Acts Compared}

There are some interesting differences between the Alberta and the New Zealand Acts.

Alberta includes-subject to the exceptions mentioned above-all 'departments or agencies' of the Government of Alberta as potentially within the Ombudsman's jurisdiction; speaking with the diffidence of an outsider, I take this to exclude little else but the legislature, the judiciary and local government."' New Zealand instead names specific departments and agencies, and although the coverage is wide, there are many exclusions besides the legislature, the judiciary and local government. This was natural in a pioneer measure instituted in an atmosphere of some opposition and more misgivings. Alberta also has the advantage of being a state in a federation, whose position in the federation relieves it from primary responsibility for foreign affairs, defence and security matters-the 'sensitive areas' bound to worry a unitary sovereign government like New Zealand's.

In all countries with the British-style system of responsible government, critics of the Ombudsman have suggested that he could undermine the necessary confidential and delicate relations between the political Ministers-the 'Cabinet'-and between them and their top civil servants. In New Zealand, there was no need to exempt 'the Cabinet' as such from the attentions of the Ombudsman, for two reasons. Firstly, under the 'listing' principle just named, the Cabinet is not named as coming within the Ombudsman's scope. But secondly —and a point which Canadian observers might not appreciate so sharply as Australian observers-the Cabinet in New Zealand, as in Australia and the United Kingdom, is a totally extra-legal body, an accidental occasional gathering of persons who happen to be Ministers of the Crown and also members of a body which is known to the law, namely the Executive Council, of which the Governor-General (Governor in Australian States) is also a member." Some of the policy decisions of Cabinet are in New Zealand translated into specific legal or administrative eifect by action in specific departments or agencies, others by formal instruments which are executed by the Governor-General in the Executive Council. But the activities of the latter are today so formal that it didn't occur to the New Zealanders to make any specific provision about secrecy for the Executive Council at all. Instead, the New Zealand Act, perhaps unnecessarily, guards against any disclosure which might imperil the secrecy of Cabinet proceedings, by empowering the Attorney-General to certify that relevant questions or documents should not be answered or produced." In Alberta, on the other hand, as in many (perhaps all) Canadian provinces, the Cabinet has not developed as an extra-legal body distinct from the Executive Council; instead it has developed within the Executive Council, formally as a Committee of that Council, and in practice it

IId. ss. 21, $20(4)$.

11 The Editor has kindly advised me that even local government matters may come under inspection indirectly where they are subject to supervision or confirmation by a department or agency, and the latter's acts or omissions are challenged.

1 See as to New Zealand. K. J. Scott. The New Zealand Constitution, 78ff; as to Australia, Sawer. Australian Government Today, chap. 13, and Councils, Ministers and Cabinets in Australia, (1956) Public Law 110.

1: Parliamentary Commissioner (Ombudsman) Act, N.2. 1962, No. 10, s. 17(1) (b). (c). 
contains all the members of the Council who matter. Hence the Alberta Ombudsman Act attends in terms, not to the problem of Cabinet secrecy, but to that of Executive Council secrecy, ${ }^{1: 3}$ which the New Zealand Act doesn't even mention. This draws attention to a little-remarked formal difference between Canadian and Australasian constitutional development. Both began with Governors-General, Governors and Lieutenant Governors exercising real powers in Executive Councils made up at first mainly of officials, and then increasingly of Ministers drawn from elective bodies. In the development of full responsible government, Australasia followed the course of having the Ministers withdraw from the Executive Council to form the 'real' executive, the Cabinet, leaving the Governor in possession of the Executive Council which became purely formal. In Canada, on the other hand, it was the Governor who withdrew from the Council, leaving the latter in possession of the Ministers. I set all this out with considerable diffidence, since I have found no Canadian work which makes the comparison in clear terms, ${ }^{1+}$ and was led on to investigate the situation only because of the difference in drafting between the Alberta and the New Zealand Acts on this question of preserving 'Cabinet' secrecy. As to the relation between top civil servants and Ministers, both Acts cheerfully take a risk with the principles of responsible government by permitting the Ombudsman to question 'recommendations' made to a Minister, and both leave to sensible adjustment in an ad hoc fashion-which has caused some discussion but no real difficulty in New Zealand-the reconciliation of this provision with the claims of Cabinet secrecy.

The New Zealand Ombudsman has to be reappointed from (triennial) Parliament to Parliament, which may give him a slightly shorter potential term of office than the five years certain of Alberta; I feel that the latter may be the better provision, serving the same necessary purpose of ensuring that the Ombudsman of the day always has the confidence of the legislature but in a way less likely to cause the Ombudsman embarrassment over the renewal of his term of office. However, in the Alberta case it might have been desirable to include expiry of the term of office as an occasion for interim appointment under 5 . 7, in case the legislature hasn't got around to making its recommendation. The Alberta Ombudsman's salary $(\$ 20,000$ p.a.) is almost equal to the highest salary offered to Deputy Ministers (= Secretaries, Permanent Heads in Australasia), and a little below that of Supreme Court puisne Judges $(\$ 21,000)$. This is an improvement on New Zealand, where the top civil servants as well as the senior judiciary are paid appreciably more than the Ombudsman who is expected to deal with them on equal terms.

Alberta has omitted the New Zealand provisions': for a fee on complaint. The New Zealand Ombudsman has found it more of a nuisance than the income can possibly be worth.

There is an almost imperceptible difference in the provisions governing the right to be heard of the department or agency concerned in an enquiry, ": which could lead to some important differences in result or

li: Alta. s. 18 (1) (a) (b).

$11 \mathrm{My}$ understanding of the Canadian position is based on scattered references to Provincial Executive Councils in Kennedy. The Constitution of Canada (2nd ed.). Provincial Executive Counclis in anderta and Saywell. The Office of Lieutenant-Governor, Macpherson, Democracy in Alberta, and Saywell. The Office of Lieutenant-Governor, the position of the Dominion Cabinet in relation to the Privy Council is similar.

16 N.Z. S. $13(3)$. 
in none, according to the office habits developed by the Alberta Ombudsman. The New Zealand Act requires the Ombudsman to offer a hearing to an affected department as soon as he considers there may be sufficient grounds for an adverse report. This does not appear in the Alberta Act, though it, like the N.Z. Act, requires the offer of a hearing before an adverse report is actually made: ${ }^{15}$ the possible difference is as to the stage when such a hearing is first held and the number of such hearings which may be required.

The Alberta Act makes no direct provision for the making of reports direct to the Press. The New Zealand Act specifically authorises Parliament to make rules providing for such publication, and such Rules have been made. The Alberta omission seems deliberate, and probably the Alberta s.23 (4) on Press privilege assumes the prior making of a report by the Ombudsman in a manner which the Act has previously specified in ss. $20(3),(4)$-that is, to the Minister, department or agency concerned, or to the Lieutenant Governor, or to the Legislature. I doubt whether the 'information' and 'comments' which he is empowered to make to the complainant under s. 21 can safely be reported by the Press under s. 23 (4), though they would themselves be privileged under s. 23(1). This suggests that the Ombudsman is not intended to use Press reporting and consequent discussion as a sanction for attention to his reports by the administration, in the manner well known in Sweden and becoming well known in New Zealand.

The acts are substantially identical on a matter which has caused some discussion in relation to the New Zealand office, namely the extent to which the Ombudsman can criticise the policy inherent in a decision. The key section in each Act is numbered 11 and the expression giving rise to the difficulty is 'relating to a matter of administration'. This expression governs the 'decisions', 'recommendations' and 'acts' which the Ombudsman is required to investigate. My earlier view was that the expression was intended to restrict the Ombudsman to criticising the way in which a policy was administered, and excluded him from criticising the policy itself, and a similar view was taken by eminent New Zealand commentators." ${ }^{3 n}$ But after some correspondence with Sir Guy Powles, the New Zealand Ombudsman, I have come to the conclusion that such a narrow interpretation of $\mathbf{s}$. 11 cannot be reconciled with the extremely wide scope of the grounds on which the Ombudsman is empowered to act in N.Z. s. 19 and Alberta s. 20. It would be absurd if the Ombudsman could challenge the reasonableness and justice of a 'law or practice' under the latter sections, but not the reasonableness of an administrative policy. Hence the more probable purpose of the reference to a 'matter of administration' in $\mathbf{S .} 11$ is to make clear that the officer is to be concerned with administration in a broad sense as distinct from the work of the Legislature, and of the Courts, and the administrative services incidental to the latter.

\section{(iii) The Ombudsman and the Lawyer}

If the activities of the Ombudsman lay wholly in the field of adminis-

16 Alta. s. 15; N.Z. s. 15.

it Alta. s. $20(6)$; N.z. S. $19(6)$.

1s Aikman and Clark. (1965) 27 N.Z.J. of Pub. Ad. 46. The U.K. Parliamentary Commissioner Act 1967, 8. 5, probably does exclude consideration of policy, since the Ombudsman must find 'maladministration'. 
tration, then while interesting to any lawyer as part of his wider education in the government of his country, and particularly interesting to administrative lawyers of the modern sort, such activities might be thought to lie outside the interests of lawyers in the narrower senseprofessionals with clients for whom technical advice must be provided on transactions and on the availability of appropriate legal remedies. However, the enquiries of Walter Gellhorn have shown that while some lawyers denigrate or ignore an Ombudsman in their country, others are glad to steer clients in his direction if they think he is most likely to solve their problems, and this is so even where substantial interests are at stake." Hence it would seem desirable for lawyers in Alberta to become familiar with the work of the Ombudsman.

It is likely enough that the Alberta Ombudsman will be influenced by the reporting practice of the New Zealand officer. The latter's annual reports contain general comments on the events of the year, and statistical tables showing numbers of complaints, proportion rejected for various reasons, proportion found justified and unjustified, and distribution of complaints and of their categories between different departments and agencies; this is all very interesting to the citizen, the politicians and the administrators concerned, and also to students of politics and public administration, but of little help to lawyers as such. But each N.Z. report also gives a summary account (without names of parties) of about 80 individual cases in which an investigation was completed or carried a considerable distance; a majority of these are cases in which the Ombudsman secured some change in the relevant administrative decision or act, but there is also an appreciable number of cases in which he thought the complaint was unjustified or at least that the circumstances didn't clearly call for his intervention. This is the sort of material, and probably (assuming there is to be no regular contact between Ombudsman and Press in Alberta) the only material from which lawyers in Alberta can expect to obtain a more precise notion than the Act provides of the basis on which the Ombudsman discharges his functions. The N.Z. case reports are arranged under departments and agencies. This is convenient for the politicians and the administration, but of little use for the lawyer. What the latter wants is something more of a conceptual classification; he wants to know something of the Jurisprudence of the Ombudsman. I do not suggest that the Ombudsman himself ought to think out his problems along conseptual lines, though some attention to the general concepts of legal analysis would help him in his work. Still less do I suggest that the very wide discretion, to be exercised on grounds of morality and the sense of fairness, which has been granted to him should ever become hardened into a set of specific rules or circumscribed discretions in the manner of English Equity. There must be no closing of the Ombudsman's register of writs, no enactment into statute of his Praetorian Edict. But without supposing any such freezing of the Ombudsman's jurisprudence, one can propose, with advantage not only for lawyers' clients but also for the theoretical study of legal evolution, that lawyers ought to ponder the Ombudsman's case reports; lawyers should rearrange them in a manner closer to the grammar of the law, and analyse their conceptual 
assumptions. For example, many of the New Zealand decisions can be grouped around the general proposition that Governments should make good the representations of their officials; $;^{20}$ this principle acts so as to extend the boundaries of our system of contract law, and of our law relating to innocent misrepresentation. An auxiliary principle emerging from the same cases is that when an official or official document speaks ambiguously, what he or it says should be construed contra Principem, and an even wider principle is that Governments should be held to a somewhat higher standard of conduct than applies to individuals. I see no reason why a complaint to an Ombudsman should not mention such matters, and cite precedents from the reports of the Ombudsman. I also suggest that while not departing from the general form of the present New Zealand report, the Ombudsman might help the lawyers by increasing the number of reported cases-especially those in which no action was taken-and setting out the reports with some consciousness that they will be perused by lawyers in the manner adumbrated above.

Finally, might I suggest that the Alberta Law Review* makes a regular feature of studies in the Jurisprudence of the Ombudsman. 